\title{
Macroplankton communities in Antarctic surface waters: spatial changes related to hydrography
}

\author{
Uwe Piatkowski
}

Institut für Meereskunde der Universität Kiel, Abteilung Fischereibiologie, Düsternbrooker Weg 20, D-2300 Kiel 1, Federal Republic of Germany

\begin{abstract}
During the Anglo-German Antarctic expedition in February 1982 macroplankton was collected in the waters off the Antarctic Peninsula. Macroplankton compositions at 36 stations were compared and degrees of similarity submitted to hierarchical cluster analysis. Results demonstrate strong spatial heterogeneity, which could be attributed to the different water masses in this region. These dissimilarities demarcate 4 provinces, each characterized by a distinct macroplankton community: (1) The 'Oceanic Community' comprises the stations influenced by the Westwind Drift; oceanic forms are typical (e.g. the hyperiid amphipod Vibilia antarctica, and the polychaete Vanadis antarctica). (2) The 'Bellingshausen Water Community' is influenced by Bellingshausen Sea water and oceanic species are scarce; large numbers of Antarctic krill Euphausia superba occur but shallow water forms are also abundant. (3) The 'Neritic Community' consists of stations in the shelf water of the southern Bransfield Strait; it is characterized by postlarvae of several fish species, and meroplanktonic larvae of benthic forms. Large krill concentrations, however, are also encountered. (4) A 'Transitional Community' exists in environments where various water masses mingle (e.g. at shelf slopes). This community lacks typical forms.
\end{abstract}

\section{INTRODUCTION}

The broad geographical distribution of macroplankton groups in the Southern Ocean has been studied and described by several authors (e.g. Mackintosh 1934, Baker 1954, David 1958). Accepting, however, that the Southern Ocean cannot be understood as a single ecosystem (Nemoto \& Harrison 1981, Hempel 1985), meso and fine-scale zooplankton surveys have been carried out in various subregions of the Southern Ocean to examine macroplankton distribution. It has become apparent that numerous taxa do not have a homogeneous distribution pattern, particularly when near-shore waters are considered

This is especially true for the Antarctic Peninsula region and our knowledge of the complex geographical distribution of the macroplankton in this area has been greatly improved in recent years (Jazdzewski et al. 1982, Hopkins 1985a,b, Mujica \& Asencio 1985, Piatkowski 1985, Witek et al. 1985, Nast 1986).

During an Anglo-German Antarctic expedition with RRS 'John Biscoe' in February 1982 (Hempel \& Hey- wood 1982, Piatkowski 1983) a zooplankton survey was conducted to describe the distribution patterns of various zooplankton and ichthyoplankton groups in the surface waters off the Antarctic Peninsula (Hagen 1985, Marschall \& Mizdalski 1985, Piatkowski 1985, Schnack et al. 1985, Siegel 1985, Kellermann 1986). Concomitant temperature and salinity profiles were measured at each plankton station to characterize the distribution of water masses, and to assist in the interpretation of the varying zooplankton distributions in the area (Heywood 1985).

The present study is based upon the extensive data sets collected during this expedition. It was the objective to search for relationships between the spatial heterogeneity of the macroplankton community structure in the surface waters and the varying water masses in the area. Such a close interrelation between hydrography and macroplankton distribution in the Southern Ocean was recently detected in the Weddell Sea (Boysen-Ennen \& Piatkowski 1988), where it provided new insight into zooplankton distribution patterns in that region. 


\section{MATERIAL AND METHODS}

Zooplankton was collected in February 1982 from the RRS 'John Biscoe' using a multiple Rectangular Midwater Trawl (RMT $1+8 \mathrm{M}$ ), described in detail by Roe \& Shale (1979). The net system consists of 2 nets fishing simultaneously with different mesh sizes (RMT 1: $330 \mu \mathrm{m}$, mouth opening ca $1 \mathrm{~m}^{2}$; RMT 8: $4.5 \mathrm{~mm}$ in the codend, mouth opening ca $8 \mathrm{~m}^{2}$ ). The multiple RMTversion employed was equipped with 3 net pairs which open and close sequentially on hydroacoustic command enabling 3 depth strata to be sampled during one haul. Standard oblique hauls were made in the depth strata 200 to $135 \mathrm{~m}, 135$ to $70 \mathrm{~m}$ (thermocline), and 70 to $0 \mathrm{~m}$ with heaving speeds of $\mathrm{ca} 0.3 \mathrm{~m} \mathrm{~s}^{-1}$ while the ship was steaming at 1.5 to 3.0 knots. For community analysis, however, the 3 depth layers were treated as one to achieve the greatest depth range. The filtered water volumes were calculated considering net speed, net angle and flow data according to the equations compiled by Roe et al. (1980) and Pommeranz et al. (1983).

Only RMT 8 hauls are considered in this study. From a total of 61 hauls conducted in the surface waters off the Antarctic Peninsula (Fig. 1), only the 36 daytime hauls (06:00 to $22.00 \mathrm{~h}$ local) were chosen for the present study in order to avoid the potentially misleading effects of diumal vertical migrating species. Samples were stored in $4 \%$ buffered formalin seawater solution immediately after each haul.

In the subsequent laboratory analysis all specimens larger than $7 \mathrm{~mm}$ minimum length or diameter were sorted from the samples and identified to the lowest possible taxon. Data on ichthyoplankton species and early life stages of the Antarctic silverfish Pleuragramma antarcticum were kindly provided by $\operatorname{Dr} A$. Kellermann, Alfred-Wegener-Institute, Bremerhaven. Chaetognaths and siphonophores were not sorted to species level because many specimens were damaged and could not be identified correctly. Numbers of the various taxa were calculated as ind per $1000 \mathrm{~m}^{3}$. Station data and results conceming the geographical and vertical distribution of the most abundant macroplankton taxa are summarized by Piatkowski $(1983,1985)$. A comprehensive presentation of the distribution patterns of all relevant macroplankton taxa is compiled in an abridged version of the author's doctoral thesis (Piatkowski 1987). Hydrographic measurements by CTD probes were made at all sampling sites and the environmental conditions during February 1982 have been described by Heywood (1985).

For the community studies an agglomerative hierarchical cluster analysis was applied to the data sets. The data were arranged in an $(n \times m)$-matrix with $n$ representing the 36 sampling stations and $m$ representing the 42 various macroplankton taxa which were encountered in the daytime samples. Calculations were carried out with computer programs of Bölter et al. (1980). Similarity degrees of stations were expressed by the Jaccard Index which groups the stations according to presence or absence of taxa only. However, the grouping of macroplankton taxa was expressed by the Canberra Metric which also considers the abundances of taxa (ind. $1000 \mathrm{~m}^{-3}$ ). Only the complete linkage method was used in order to obtain strong separations of the

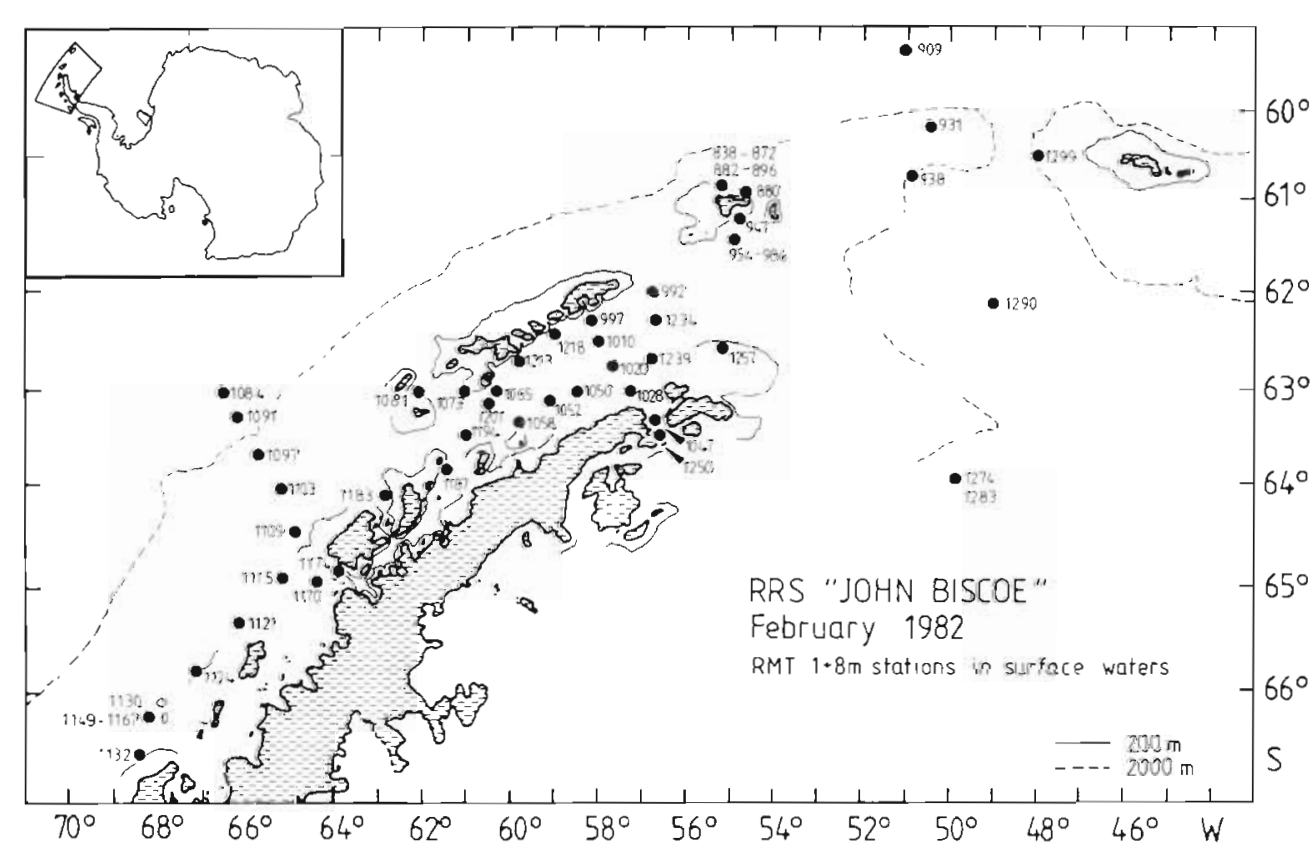

Fig. 1 Locations of sampling stations in the waters off the Antarctic Peninsula 
groupings. Sneath \& Sokal (1973) and Steinhausen \& Langer (1977) have given comprehensive reviews of these procedures for multivariate data analysis.

\section{RESULTS}

\section{Hydrography}

Heywood (1985) presented a comprehensive description of the water mass distribution during the survey. Only a brief account of the hydrographic features relevant to the macroplankton distribution will be given here. The main geographical locations and surface currents of the area are charted in Fig. 2. In general, water masses from the Bellingshausen Sea, the southern Drake Passage which is under the influence of the Westwind Drift, and the Weddell Sea characterize the complex hydrography of the waters surrounding the Antarctic Peninsula. Within the Bransfield Strait these water masses meet and mingle, creating hydrographic fronts which determine the distribution of the epipelagic zooplankton (e.g. Clowes 1934, Deacon 1937. Heywood 1985)

The vertical distributions of isotherms and isohalines along 2 transects within the investigated area are shown in Figs. 3 and 4. They were compiled from CTD data supplied by Heywood (pers. comm.). The Scotia Sea and the southern Drake Passage were characterized by the Westwind Drift which flows in an easterly direction north of the Peninsula. A warmed surface layer was notable in February 1982 (Fig. 3), with temperatures of

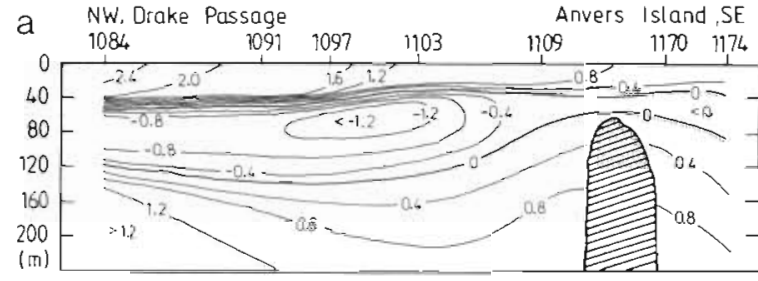

(Scale) $0 \longrightarrow 50 \mathrm{~km} \quad$ TEMPERATURE $\left({ }^{\circ} \mathrm{C}\right)$

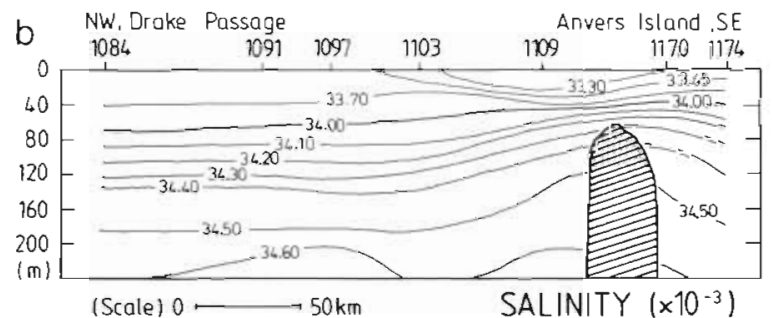

Fig. 3. Hydrographic profiles along a transect from the southern Drake Passage to Anvers Island. (a) Temperature, (b) salinity

$>1.5^{\circ} \mathrm{C}$ and salinities ranging from 33.30 to $34.40 \%$. From the southwest, water masses from the Bellingshausen Sea penetrate into the Bransfield Strait and flow along the northern part of the Strait in a northeasterly direction. During February 1982 solar radiation raised the surface temperature and ice-melt lowered the salinity of these water masses (Fig. $4 ; 0.8$ to $1.5^{\circ} \mathrm{C}, 33.90$ to $34.35 \%$ S). Colder and more saline Weddell Sea water $\left(-1.3\right.$ to $0.7^{\circ} \mathrm{C} ; 34.40$ to $\left.34.42 \% \mathrm{~S}\right)$ entered the Strait through the Antarctic Sound and around Joinville Island (Fig. 4). It formed a counter-current flowing

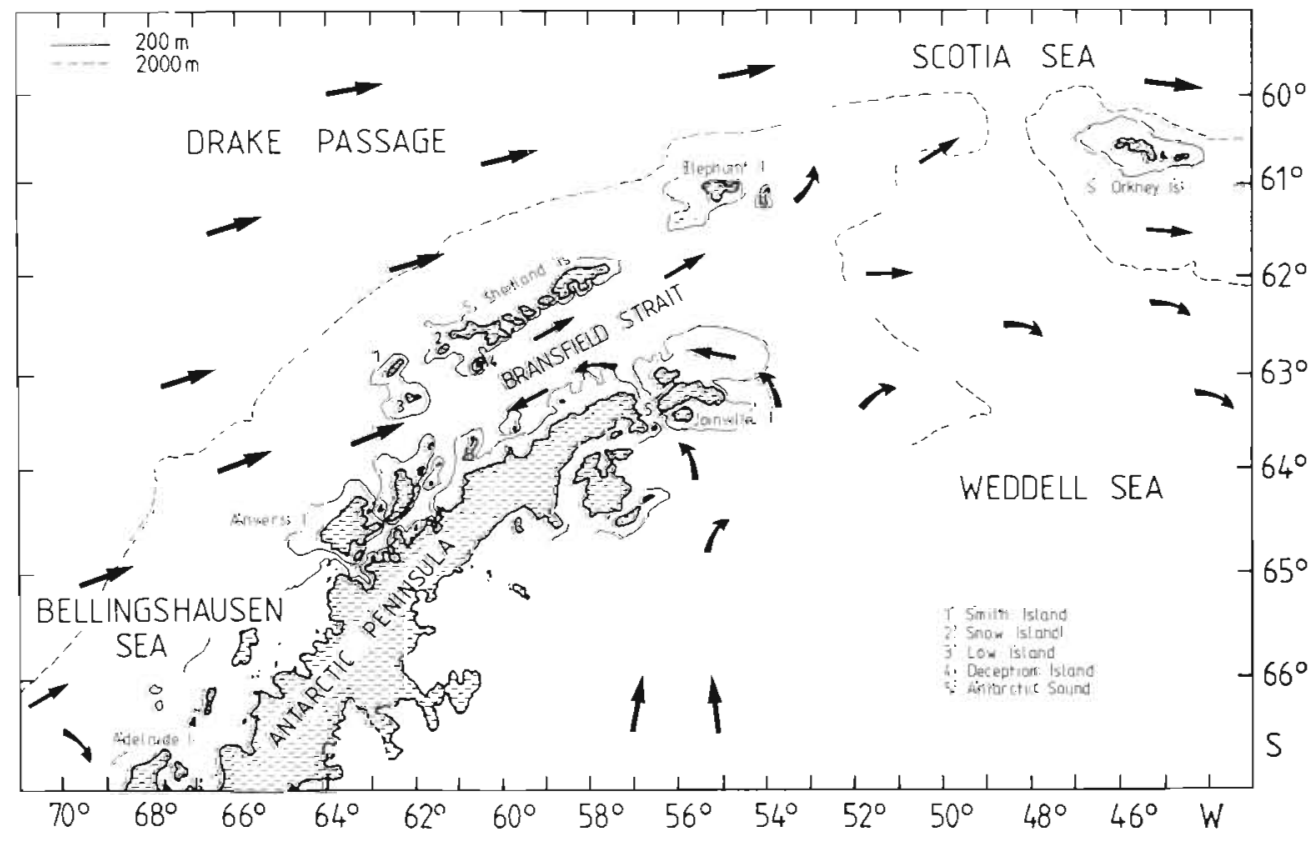

Fig. 2. Main surface currents in the investigated area 


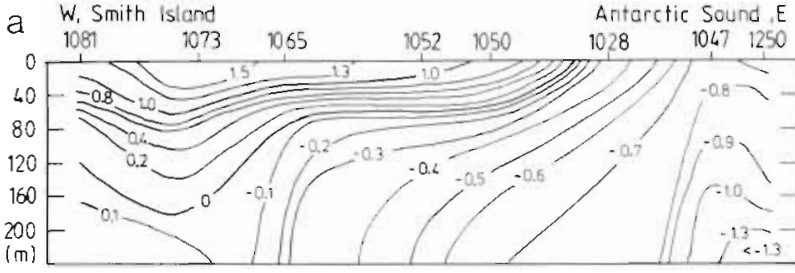

(Scale) $0 \longmapsto 50 \mathrm{~km}$

TEMPERATURE $\left({ }^{\circ}[)\right.$

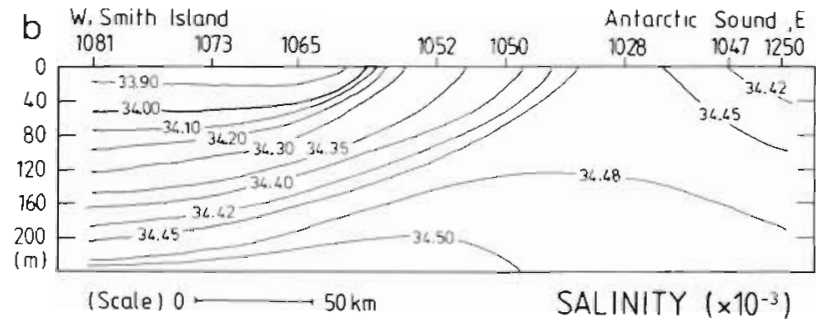

Fig. 4. Hydrographic profiles along a transect within the Bransfield Strait from Smith Island to the Antarctic Sound

(a) Temperature, (b) salinity

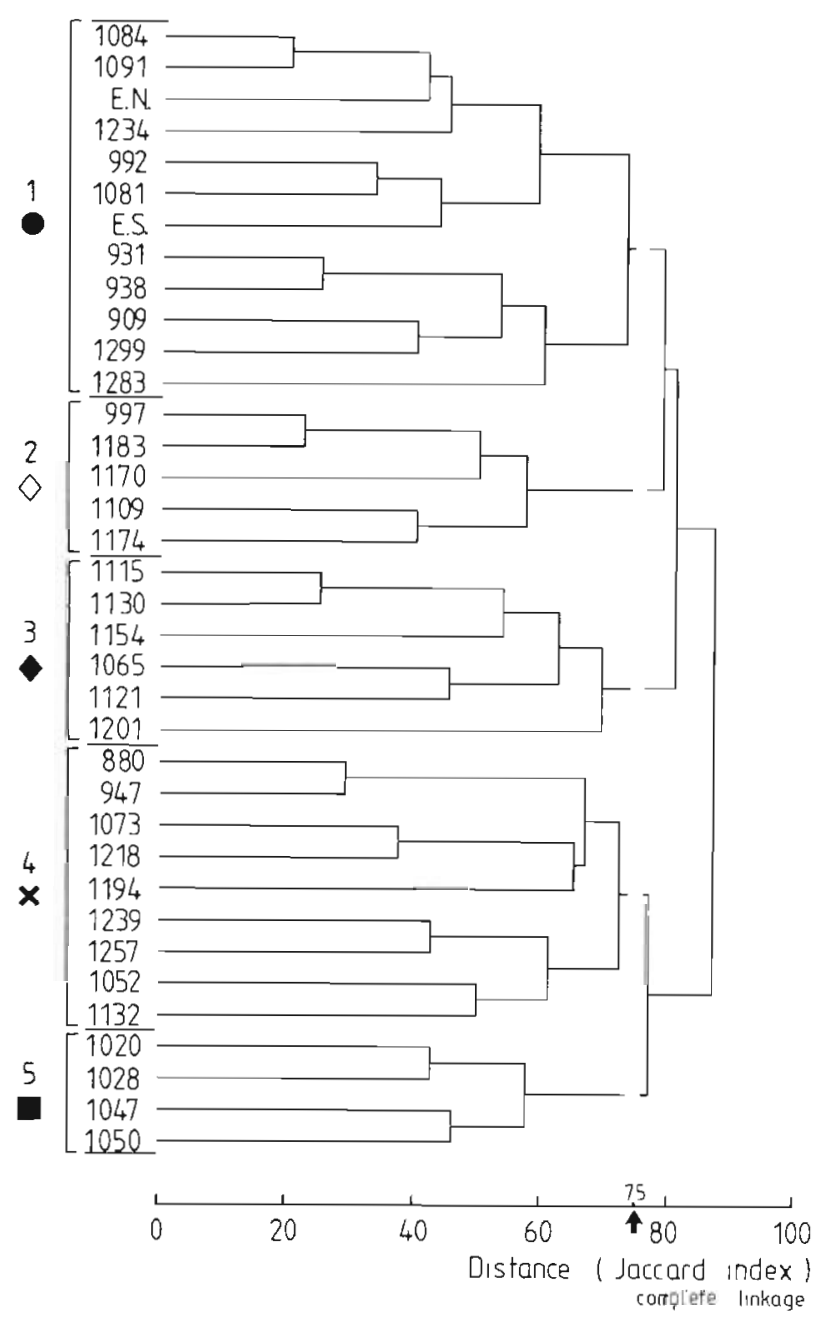

Fig. 5. Cluster analysis dendrogram of sampling stations. Symbols explained in Fig. 6. EN = time station north of Elephant Island, ES = time station south of Elephant Island southwards along the shelf of the southern Bransfield Strait. In the middle of the Strait, where Bellingshausen Sea water and Weddell Sea water meet, a complex hydrographic front developed (Fig. 4)

\section{Clusters of stations}

A dendrogram of the similarities of the macroplankton compositions of the sampling stations revealed 5 station groupings if a critical similarity degree of 75 is applied (Fig. 5). The geographical distribution of the 5 station groupings is shown in Fig. 6. Cluster 1 (the 'Oceanic Community') comprises all oceanic stations situated offshore and above the shelf slopes. Four of the 5 stations of Cluster 2 are near Anvers Island (northern Bellingshausen Sea) and one (Stn 997) is located in the northern Bransfield Strait. All these stations, and those of Cluster 3, are characterized by Bellingshausen Sea water and therefore have been combined to form a 'Bellingshausen Water Community'. The fourth cluster ('Transitional Community') consists of stations which are heterogeneous both hydrographically and geographically. These stations are mainly situated in the central Bransfield Strait and near Elephant Island in regions where the various water masses mingle. Cluster 5 ('Neritic Community') is composed of stations in the Antarctic Sound and over the shelf of the Antarctic Peninsula lying within the Bransfield Strait; areas of Weddell Sea water.

\section{Clusters of macroplankton taxa}

A second cluster analysis was applied to the data set in order to demonstrate similarities between the macroplankton taxa according to their geographical distribution patterns. The grouping dendrogram of the taxa was dependent on abundance and co-occurrence at the sampling stations (Fig. 7).

A critical distance degree of 8 was chosen to differentiate 3 large and 5 small clusters of macroplankton taxa. The first cluster consists of 10 species. Except for the pteropods Limacina helicina and Clione limacina and the hyperiid amphipod Hyperoche medusarum, all members of this group are typical near-shore forms which inhabit the depth strata close to the sea floor. The second block comprises 17 taxa which show an affinity to oceanic stations as well as to stations in the Bellingshausen Sea water. However, some typical near-shore forms are also included (the gammarid amphipods Orchomene plebs, the euphausiid Euphausia crystallorophias and the early life stages of the notothenioid fish species Notothenia kempi and pleuragramma antarcticum). (luster 3 represents 6 
Fig. 6. Cluster classification of sampling stations as revealed by dendrogram in Fig. 5
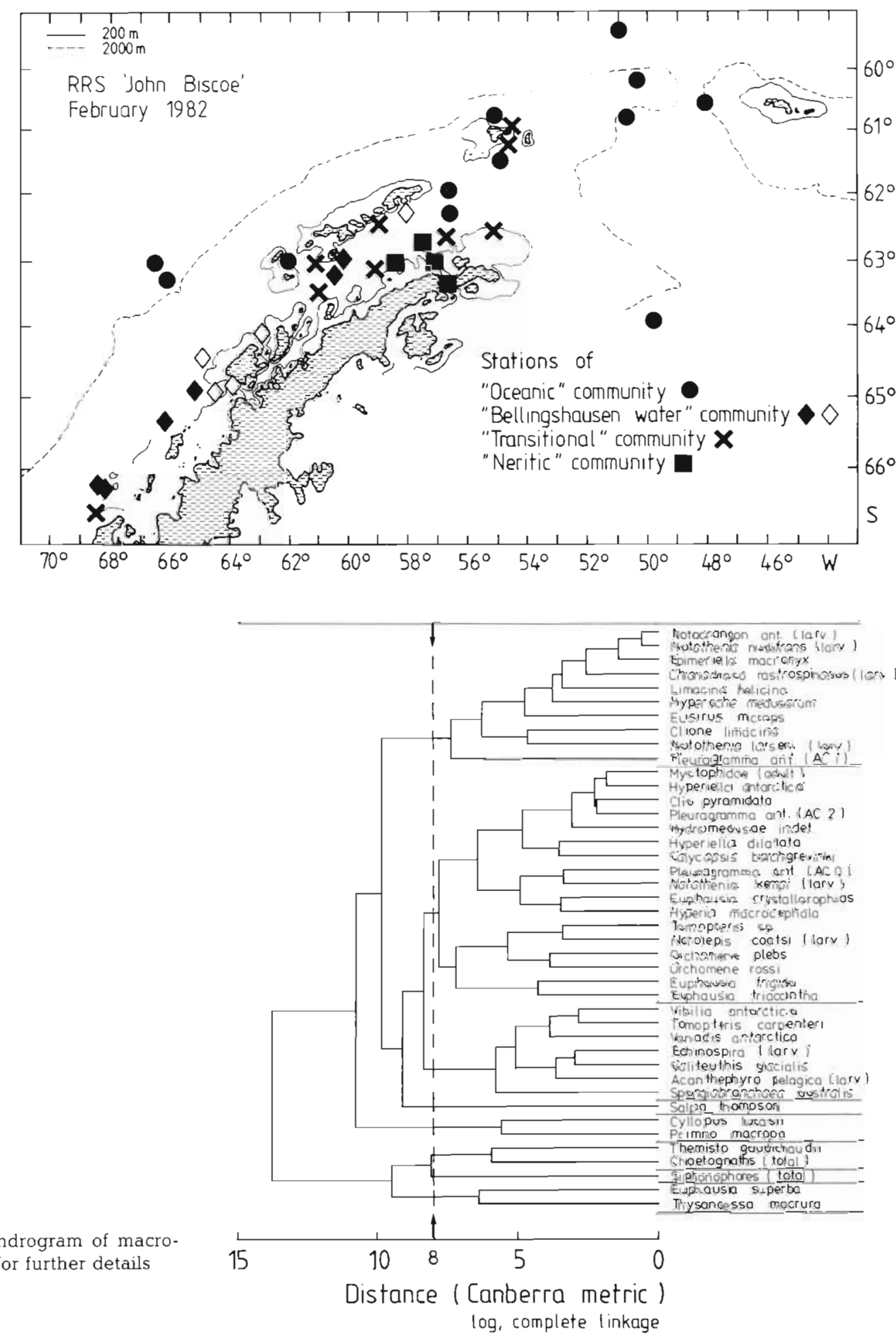

Fig. 7. Cluster analysis dendrogram of macroplankton taxa. See text for further details amphipods Cyllopus lucasii and Primno macropa (Cluster 5) occur regularly but with low abundances at almost all stations of the 'Oceanic Community' and the 'Bellingshausen Water Community'. The 5 taxa of

Clusters 6 to 8 are by far the most abundant macro- oceanic species and one meroplanktonic larva which is an echinospira form of an unknown lamellariid gastropod larvae. The remaining 5 clusters consist of only 1 or 2 taxa. The tunicate Salpa thompsoni (Cluster 4) is an abundant species at oceanic stations. The hyperiid 
Table 1. Compilation of station communities and associations of macroplankton taxa with the abscissa showing the sequence of station clusters (sequence as in Fig. 5) and the ordinate that of taxon groupings as revealed from cluster analysis. For Pleuragramma antarcticum: $\mathrm{AC} 0=$ age class $0, \mathrm{AC} 1=$ age class $1, \mathrm{AC} 2$ =age class 2 according to Hubold (1985). OC: Oceanic Community; BWC: Bellinghausen Water Community; TC: Transitional Community; NC: Neritic Community. For further explanations see text

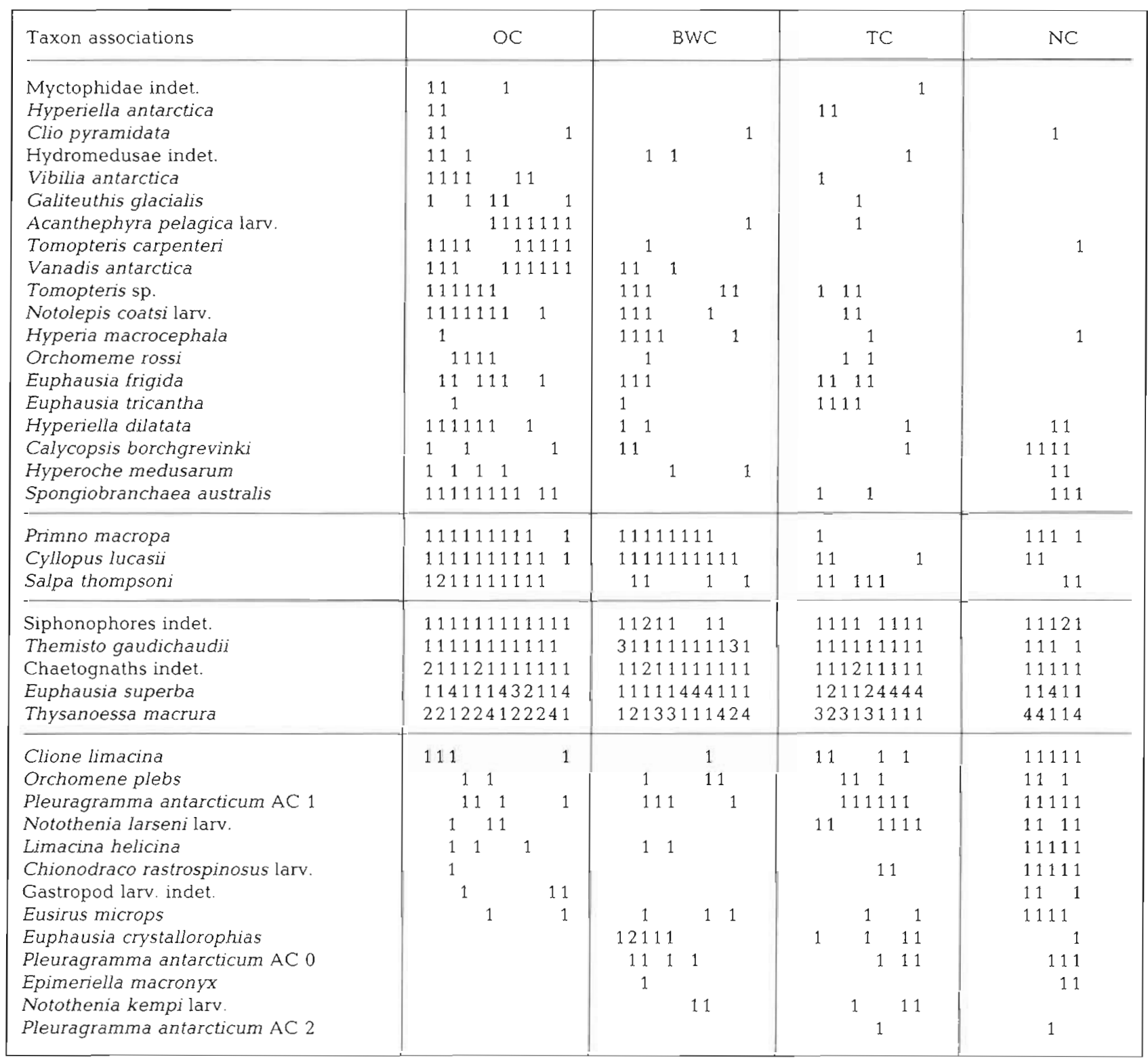

plankton taxa of the area, and they occur at nearly every station. They are separated from all other clusters because they show no affinity to any of the other associations due to their high abundance everywhere.

\section{Relation between station clusters and macroplankton taxa clusters}

In order to demonstrate the relationship between the communities of stations and the groupings of macroplankton taxa, a matrix was compiled with the abscissa indicating the sequence of the station clusters (communities of stations) and the ordinate that of the taxon clusters (associations of species) (Table 1 ). Thus, a species inventory could be provided for each station. In the interests of clarity, however, the sequence of the macroplankton taxa cluster was changed and Clusters 4 and 5, and 6 to 8 , respectively, were combined. The decapod larva Notocrangon antarcticus and the postlarva of the notothenioid fish Notothenia nudifrons were excluded from the 
compilation because they appeared only once in the daytime samples.

The occurrence of the various taxa at each station is expressed as a dominance degree. The numerals symbolize the different degrees: 4 indicates that the taxon contributes $>75 \%$ of the total individual number at the station considered, 3 indicates 50 to $75 \%, 2$ indicates 25 to $50 \%$, and 1 indicates $<25 \%$. The vertical lines border the station groupings and the horizontal lines divide the species associations.

The first association comprises 19 taxa which show clear affinity to the stations of the 'Oceanic Community'. This affinity diminishes with increasing rank, i.e. the latter taxa of this association increasingly become more regular components of the other station communities. The second group comprises 3 species which occur regularly in the 'Oceanic Community' as well as in the 'Bellingshausen Water Community'. The third association comprises 5 taxa which appear in high abundances at all sampling sites. These taxa are 'generalists', i.e. they show no particular affinity for, nor avoidance of any, of the station communities. The fourth group comprises 13 taxa which with increasing rank become more and more absent in the 'Oceanic Community'. They have affinities to the 'Bellingshausen Water Community', 'Transitional Community' or 'Neritic Community'. However, these affinities are not as pronounced as those shown by species of the first grouping to the 'Oceanic Community'.

\section{DISCUSSION}

Cluster analysis has become a well-accepted technique for analyzing complex distribution patterns from marine ecological data (Field et al. 1982, Bölter \& Meyer 1986). Only recently, however, has this method been applied to search for 'biotic' patterns in zooplankton data sets collected in the Southern Ocean. Miller (1985) describes 'faunal dissimilarities' between 2 subAntarctic islands (Prince Edward and Gough Islands) by comparing macroplankton compositions of the areas. Hubold et al. (1988) and Boysen-Ennen \& Piatkowski (1988) classified zooplankton communities in the Weddell Sea. The successful separation of the various communities in these studies provided a close relationship between the zooplankton distribution patterns and the distribution of water masses in these areas.

Although a more complex hydrographic regime exists in the Antarctic Peninsula region than in most other parts of the Southern Ocean, the present study has succeeded in separating 4 station communities or 'faunal provinces' and at least 4 species associations (Figs. 5 to 7 ; Table 1 ). Thus, the surface waters off the Antarctic Peninsula can be divided into 4 subunits. This corroborates the spatial heterogeneity of the macro- plankton distribution in this area referred to in the introduction.

The well-pronounced hydrographic front within the Bransfield Strait (Fig. 3; Heywood 1985) acted as an effective barrier, separating the 'Neritic Community' on the southern shelf of the Bransfield Strait from the 'Bellingshausen Water Community' and the 'Transitional Community' in the northwestern parts of the Strait. This is well illustrated by the distribution patterns of the taxa.

For example, the polychaete Tomopteris sp., a common component in the 'Bellingshausen Water Community' strongly avoids the cold Weddell Sea water which characterizes the 'Neritic Community'. Further, the abundances of the commonly present amphipod Themisto gaudichaudii and the tunicate Salpa thompsoni were much greater in the 'Bellingshausen Water Community' than in the 'Neritic Community' (Piatkowski 1985, 1987).

The 'Bellingshausen Water Community' is characterized by water masses from the Bellingshausen Sea. A great number of taxa occur in this community which are also abundant in the 'Oceanic Community' (Table 1). Therefore, the 'Bellingshausen Water Community' can be interpreted as a southwesterly extension of the 'Oceanic Community'. This is also supported by the very close linkage of the station clusters of the 2 communities (Fig. 5). In the western part of the investigated area the 'Bellingshausen Water Community extends to the shelf region of the Antarctic Peninsula (between $63^{\circ}$ and $68^{\circ} \mathrm{W}$; Fig. 6). South of it, on the Peninsula shelf, no 'Neritic Community' could be detected and even a 'Transitional Community' was evident at only one station. However, the shallow areas of this shelf region which may correspond to the stations of the 'Neritic Community' in the southern Bransfield Strait could not be sampled due to heavy ice conditions.

Hydrographic fronts functioning as barriers between biotic communities are well-described phenomena in marine ecology (Brandt \& Wadley 1981, Olson \& Backus 1985). At such fronts a mixed community can develop characterized by species of both adjacent communities. The 'Transitional Community' can be interpreted as such a community. It is not characterized by a typical spectrum of taxa (Table 1). Indicator species, i.e. species or higher taxa occurring exclusively in one community and only sporadically at the nearest stations of an adjacent community, are lacking because of the mixing of faunal components from the neighbouring communities. Indicator species are found only for the 'Oceanic Community'. These are the hyperiid amphipod Vibilia antarctica, the cranchiid squid Galiteuthis glacialis and the polychaetes Tomopteris carpenteri and Vanadis antarctica (Table 1). Thus, the 
'Oceanic Community' is the best defined one because only here can indicator species be detected. Their description is an important tool in biogeographic studies to characterize faunal provinces. The other communities are mainly derived by changes in the abundance of species rather than by changes in species composition. With regard to species, the 'Oceanic Comnunity' presented here corresponds closely to the 'Oceanic Community' described for the Weddell Sea (Boysen-Ennen \& Piatkowski 1988).

Zooplankton communities for the waters off the Antarctic Peninsula have also been described by other authors. Jazdzewski et al. (1982) divided the area into 2 zones widely dependent on the water mass distribution: the 'Antarctic Zone' and the 'Continental Zone', the boundary of these zones running along the continental slope. The 'Antarctic Zone' very much resembles the 'Oceanic Community' of this study and the 'Continental Zone' includes the remaining communities.

Rakusa-Suszczewski (1983) classified 3 communities: 'antarctic', 'intermediate', and 'continental'. He also included phytoplankton and small zooplankton in his investigations in addition to macroplankton. He considered pteropods and chaetognaths as being typical macroplankton forms of the 'antarctic' community of the southern Drake Passage, thus being comparable with the 'Oceanic Community' of the present study. His 'intermediate' community is located in the areas where Bransfield Strait water masses and the Weddell Sea water masses mix, thus being comparable with the 'Transitional Community' of this study. Finally, Rakusa-Suszczewski's 'continental' community applies to the Bransfield Strait and coastal regions, with Euphausia superba and Themisto gaudichaudij dominating. This probably corresponds to the 'Bellingshausen Water Community' and the 'Neritic Community' of this study.

The community classifications of Jazdzewski et al. (1982) and Rakusa-Suszczewski (1983) were based upon a very wide spatial scale. In contrast, the community studies of Hopkins (1985a,b) and Miller (1985) were based on a relatively restricted range. All, however, emphasize the interrelation of plankton and water masses. The present study shows that the correlation is very close. This becomes particularly evident if the geographical locations of the communities (Fig. 6) are superimposed on a map showing the various water masses of the region (Heywood 1985).

Parcels of surface water from the Weddell Sea and the Bransfield Strait appeared to be moving alternatively through the Elephant Island area (Heywood 1985). This phenomenon is well documented in the present study by 2 stations of the 'Transitional Community' lying in the Elephant Island shelf region. They are characterized by a number of macroplankton species (e.g. Euphausia crystallorophias) bound to the cold water masses of the Weddell Sea and the Bellingshausen Sea (Table 1). This example clearly demonstrates the transport of macroplankton species with the movement of water masses (e.g. Weddell Sea water along the Weddell-Scotia Confluence). Similar drift has been shown for larval Pleuragramma antarcticum in the coastal current of the Weddell Sea. Their presence or absence likewise characterizes the zooplankton community in that region (Hubold et al. 1988). The communities and correlations delineated here refer only to the short period of the austral summer of 1981/ 82. Identical communities may exist also during other seasons and in other years. Clarification of this aspect is the subject of another investigation (Siegel \& Piatkowski in press)

Acknowledgements. The author thanks the crew of the 'John Biscoe' and all scientists of the cruise in February 1982 for excellent cooperation in field work. Logistical and financial support was given from the Alfred-Wegener-Institute, Bremerhaven and the British Antarctic Survey, Cambridge Mrs E. Mizdalski, Alfred-Wegener-Institute, carefully sorted most of the zooplankton material. Prof. C. C. E. Hopkins and Drs W. Hagen, R. B. Heywood and M. Meyer critically read the manuscript and provided much helpful comments and discussions. This paper was presented as an oral contribution at the 5th SCAR-Symposium in Hobart, Australia.

\section{LITERATURE CITED}

Baker, A. de C. (1954). The circumpolar continuity of Antarctic plankton species. 'Discovery' Rep. 27: 201-219

Bölter, M., Meyer, M. (1986). Structuring of ecological data sets by methods of correlation and cluster analysis. Ecol. Modelling 32: 1-13

Bölter, M., Meyer, M., Probst, B. (1980). A statistical scheme for structural analysis in marine ecosystems. Ecol. Modelling 9: 143-151

Boysen-Ennen, E, Piatkowski, U. (1988). Meso- and macrozooplankton communities in the Weddell Sea, Antarctica. Polar Biol. 9: 17-35

Brandt, S. B., Wadley, V. A. (1981). Thermal fronts as ecotones and zoogeographic barriers in marine and freshwater systems. Proc. Ecol. Soc. A.ust. 11; 13-26

Clowes, A. J. (1934). Hydrology of the Bransfield Strait. DisCovery' Rep. 9: 1-64

David, P. M. (1958). The distribution of the Chaetognatha of the Southern Ocean. 'Discovery' Rep. 29: 200-229

Deacon, G. E. R. (1937). The hydrology of the Southern Ocean. 'Discovery' Rep. 15: 1-124

Field, J. G., Clarke, K. R., Warwick, R. M. (1982). A practical strategy for analysing multispecies distribution patterns. Mar Ecol Prog. Ser. 8: 37-52

Hagen, W. (1985). On distribution and population structure of Antarctic Chaetognatha. Meeresforsch. 30: 280-291

Hempel, G. (1985). On the biology of polar seas, particularly the Southern Ocean. In: Gray, J. S., Christiansen, M. E. (eds.) Marine biology of polar regions and effects of stress on marine organisms. John Wiley, Chichester, p. 3-34 
Hempel, G., Heywood, R. B. (1982). Joint biological expedition on RRS 'John Biscoe', February 1982. Rep. Polar Res. 5: 1-39

Heywood, R. B. (1985). Environmental conditions in the Antarctic Peninsula area of the Southern Ocean during the Anglo-German joint biological expedition, February 1982 Meeresforsch. 30: 220-239

Hopkins, T L. (1985a). The zooplankton community of Croker Passage, Antarctic Peninsula. Polar Biol. 4: 161-170

Hopkins, T L. (1985b). Food web of an antarctic midwater ecosystem. Mar Biol. 89: 197-212

Hubold, G. (1985). On the early life history of the high Antarctic silverfish, Pleuragramma antarcticum. In: Siegfried, W. R., Condy, P. R., Laws, R. M. (eds.) Antarctic nutrient cycles and food webs. Proc. 4th SCAR Symp. Antarct. Biol. Springer, Berlin, p. 445-451

Hubold, G., Hempel, I., Meyer, M. (1988). Zooplankton communities in the southern Weddell Sea. Polar Biol. 8: $225-233$

Jazdzewski, K., Kittel, W., Lotocki, K. (1982). Zooplankton studies in the southern Drake Passage and in the Bransfield Strait during the austral summer (BIOMASS-FIBEX, February-March 1981). Pol. Polar Res. 3: 203-242

Kellermann, A. (1986). Geographical distribution and abundance of postlarval and juvenile Pleuragramma antarcticum (Pisces, Notothenioidei) off the Antarctic Peninsula. Polar Biol. 6: 111-119

Mackintosh, N. A. (1934). Distribution of the macroplankton in the Atlantic sector of the Antarctic. 'Discovery' Rep. 9: $67-160$

Marschall, S., Mizdalski, E. (1985). Euphausid larvae in plankton samples from the vicinity of the Antarctic Peninsula. Rep. Polar Res. 21: 1-47

Miller, D. G. M. (1985). Marine macroplankton of two subAntarctic islands. In: Siegfried, W. R., Condy, P. R., Laws, R. M. (eds.) Antarctic nutrient cycles and food webs. Proc. 4 th SCAR Symp. Antarct. Biol. Springer, Berlin, p. 255-361

Mujica, A. R. Asencio, V. V. (1985). Fish larvae, euphausiids and community structure of zooplankton in the Bransfield Strait (SIBEX-Phase 1) 1984. INACH (Instituto Antártico Chileno) Ser. Sci. 33: 131-154

Nast, F. (1986). Changes in krill abundance and in other zooplankton relative to the Weddell-Scotia Confluence around Elephant Island in November 1983, November 1984 and March 1985. Arch. FischWiss. 37. 73-94

Nemoto, T., Harrison, G. (1981). High latitude ecosystems. In: Longhurst, A. R. (ed.) Analysis of marine ecosystems. Academic Press, London, p. 95-126

Olson, D., Backus, R. (1985). The concentrating of organisms

This article was submitted to the editor at fronts: a cold-water fish and a warm-core Gulf Stream ring. J. mar. Res. 43: 113-137

Piatkowski, U. (1983). Joint biological expedition on RRS 'John Biscoe', February 1982 (II). Data of micronekton and zooplankton hauls. Rep. Polar Res. 11. 1-40

Piatkowski, U. (1985). Distribution, abundance and diurnal migration of macrozooplankton in Antarctic surface waters. Meeresforsch. 30: 264-279

Piatkowski, U. (1987). Zoogeographical investigations and community analyses on Antarctic macroplankton. Rep. Polar Res. 34: 1-150 (German; English summary)

Pommeranz, T., Hermann, C., Kühn, A. (1983). Mouth angles of the rectangular midwater trawl (RMT $1+8$ ) during paying out and hauling. Meeresforsch. 29: 267-274

Rakusa-Suszczewski, S. (1983). The relationship between the distribution of plankton biomass and plankton communities in the Drake Passage and the Bransfield Strait (BIOMASS-FIBEX, February-March 1981). In: Nemoto, T., Makuda, T. (eds.) Proc. BIOMASS Colloq. 1982. Mem. natn. Inst. Polar Res., Tokyo (Spec. Issue) 27: 77-83

Roe, H. S. J., Baker, A. de C., Carson, R. M., Wild, R., Shale, D. M. (1980). Behaviour of the Institute of Oceanographic Science's rectangular midwater trawls: theoretical aspects and experimental observations. Mar. Biol. 56: 247-259

Roe, H. S. J., Shale, D. M. (1979). A new multiple rectangular midwater trawl (RMI $1+8 \mathrm{M}$ ) and some modifications to the Institute of Oceanographic Science's RMT $1+8$. Mar. Biol. 50: 283-288

Schnack, S. B., Marschall, S., Mizdalski, E. (1985). On the distribution of copepods and larvae of Euphausia superba in Antarctic waters during February 1982. Meeresforsch. 30: $251-263$

Siegel, V (1985). The distribution pattern of krill, Euphausia superba, west of the Antarctic Peninsula in February 1982. Meeresforsch. 30: 292-305

Siegel, V., Piatkowski, U. (in press). Variability in the zooplankton community off the Antarctic Peninsula. In: Kerry, K., Hempel, G. (eds.) Antarctic ecosystems - ecological change and conservation. Springer, Berlin

Sneath, P. H., Sokal, R. R. (1973). Numerical taxonomy. Freeman and Co., San Francisco

Steinhausen, D., Langer, K. (1977). Clusteranalyse. Einführung in Methoden und Verfahren der automatischen Klassifikation. Walter de Gruyter, Berlin

Witek, Z., Kittel, W., Czykieta, H., Zmijewska, M. I., Presler, E. (1985). Macrozooplankton in the southern Drake Passage and in the Bransfield Strait during BIOMASS-SIBEX (December 1983-January 1984). Pol. Polar Res. 6: 95-115

Manuscript first received: November 22, 1988

Revised version accepted: May 16, 1989 